\title{
RESPONSE OF BARLEY ON SEAWEED BIOSTIMULANT APPLICATION
}

\author{
Małgorzata Szczepanek ${ }^{1}$, Bogusława Jaśkiewicz ${ }^{2}$, Karol Kotwica1 \\ ${ }^{1}$ UTP University of Science and Technology, Poland \\ ${ }^{2}$ Institute of Soil Science and Plant Cultivation State Research Institute, Poland \\ Malgorzata.Szczepanek@utp.edu.pl
}

\begin{abstract}
In some regions of the world, there is a risk of limiting crop production due to the growing pressure of biotic and abiotic factors. It is mostly connected with the forecasted climatic changes. Hence, alternative methods for supporting plant growth are sought for, and among them, biostimulants can play a significant role. The three-year (2009 - 2011) field experiment with spring barley (Hordeum vulgare L.) was conducted in Poland to assess the response of grain yield, yield components, as well as the content and uptake of N, P and $\mathrm{K}$ in grain to differentiated times and to a dose of seaweed (Ecklonia maxima Osbeck) biostimulant Kelpak application. Preparation was applied in a dose of $2 \mathrm{~L} \mathrm{ha}^{-1}$ at BBCH 22 (early treatment) or in a dose of $2 \mathrm{~L} \mathrm{ha}^{-1}$ at BBCH 31 (late treatment), as well as two times, $1.5 \mathrm{~L} \mathrm{ha}^{-1}$ each, in both phases. The study indicated that the biostimulant had a favourable effect on the root weight, grain number per spike, thousand grain weight and seed yield in early treatment as compared with the control. Early application also had a positive effect on $\mathrm{N}$ and $\mathrm{P}$ uptake in the grain yield. Favourable response of barley to the application of biostimulant shows the usefulness of the seaweed extract in the cultivation technology of this crop.
\end{abstract}

Key words: root weight, yield component, grain yield, macroelements.

\section{Introduction}

Barley (Hordeum vulgare L.) is among the most economically vital cereal crops. It is used mostly as a raw material for feed production. An increase in the meat production generate an increasing demand for grain of fodder cereals (FAOSTAT, 2018). At the same time, there is a risk of limiting grain production due to the growing pressure of environmental factors, mostly connected with an increased risk of drought and heat stress (Sharma et al., 2014). Hence, alternative methods for supporting plant growth and hardiness are sought for, and among them, biostimulants are highly promising (Craigie, 2011; Khan et al., 2009; Kocira et al., 2017; Kotwica et al., 2014; Sangha et al., 2014; Sharma et al., 2014; Szczepanek, Wszelaczyńska, \& Pobereżny, 2018). Agricultural biostimulants are organic substances that are applied to plants or soils to increase crop tolerance to stress, and the quantity and quality of yield (EBIC, 2018). Among the preparations from this group, biostimulants produced from marine algae (e.g. Ascophyllum nodosum, Ecklonia maxima, Laminaria digitate, Fucus serratus, Durvillaea potatorum) constitute a significant part (Craigie, 2011; Sharma et al., 2014). Currently, it is known that the use of macroalgal extracts can bring many benefits in the cultivation of agricultural crops, but the reasons for the positive results are not fully understood (Sharma et al., 2014). Nowadays, the economics of crop production limit the use of biostimulants mainly to high-value horticultural crops. However, high prices for fertilizers and pesticides may change this situation, and these preparations exhibiting activity for promoting plant growth and stress tolerance will become commonly used in many agricultural crops (Shanga et al., 2014; Sharma et al., 2014). Learning the effects for use of alga biostimulants requires research concerning the method of application, which forms the basis for increasing the effectiveness of those preparations. The aim of the study was to assess the response of spring barley yield and yield components, as well as the content and uptake of macronutrients in grain to differentiated times (cereal developmental stages) and a dose of algae (Ecklonia maxima Osbeck) biostimulant Kelpak application.

\section{Materials and Methods}

The current study was based on two strict field experiments located in Poland, in Kuyavian-

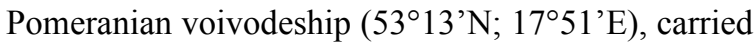
out for three years $(2009,2010$ and 2011). Most of the time, the rainfall and thermal conditions in the area of the study are favourable for wheat and barley cultivation. The cereal growing period begins on the first days of April and ends on the last days of July. The long-term mean of total precipitation in this period amounted to $197 \mathrm{~mm}$. In 2009, the lowest precipitation was recorded in April $(0.4 \mathrm{~mm})$ and in 2010 in June $(18.1 \mathrm{~mm})$. In 2011, the rainfall during the growing period of barley (from April to July) was the lowest $(59.2 \mathrm{~mm})$.

Field experiments were located on the Haplic Luvisol (Cutanic) soil (IUSS Working Group WRB). The soil at experimental fields was characterized by a low content of organic carbon $7.55-7.8 \mathrm{~g} \mathrm{~kg}^{-1}$ (PN-ISO 10694) and a low content of the total nitrogen $0.69-0.75 \mathrm{~g} \mathrm{~kg}^{-1} \mathrm{NH}_{4}-\mathrm{N}$ and $\mathrm{NO}_{3}-\mathrm{N}$ (PN-R-04028). The content of available phosphorus (PN-R-04023) and potassium (PN-R-04022) were $190-210 \mathrm{mg} \mathrm{kg}^{-1}$ (high) and $95-150 \mathrm{mg} \mathrm{kg}^{-1}$ (medium), respectively. The content of magnesium (PN-R-04020) was very low $\left(<20.0 \mathrm{mg} \mathrm{kg}^{-1}\right)$. The soil was characterised by a slight acidic reaction ( $\mathrm{pH}$ in 1 mol KCL $5.7-6.1$ ) (PN-ISO 10390). 
The field study was conducted as strict onefactorial experiment, in four replications. The plots had an area of $12 \mathrm{~m}^{2}$. The subject of the study was the spring barley (Hordeum vulgare) cultivar 'Nuevo'. In the experiment, the seaweed biostimulant Kelpak was used during three successive growing seasons. Biostimulant Kelpak is obtained from macroalga (Ecklonia maxima Osbeck) belonging to the division of brown algae (Phaeophyta), collected on the south coast of Africa. In the processing of algae, Cold Cellular Burst Technology is used, thanks to which the full physiological activity of all substances is preserved. The bioproduct Kelpak contains phytohormones like auxins $\left(11 \mathrm{mg} \mathrm{L}^{-1}\right)$ and cytokinins $\left(0.031 \mathrm{mg} \mathrm{L}^{-1}\right)$, alginians, amino acids, and brassinosteroids. Kelpak was applied as an early treatment (in a single dose of $2 \mathrm{~L} \mathrm{ha}^{-1}$, at tillering - two tillers detectable, $\mathrm{BBCH} 22$ ) or as a late treatment (in a single dose of $2 \mathrm{~L} \mathrm{ha}^{-1}$, at stem elongation, first node at least $1 \mathrm{~cm}$ above tillering node, BBCH 31), as well as a sequential treatment (two times, $1.5 \mathrm{~L} \mathrm{ha}^{-1}$ in each of both growth stages, BBCH 22 and BBCH 31). Preparation was applied as aqueous solution in a dose of $300 \mathrm{~L} \mathrm{ha}^{-1}$. The three kinds of applications of the seaweed biostimulant were compared with the control (without treatment) group.

The spring barley was sown on $2-4$ April in germinate able seeds of 430 per $1 \mathrm{~m}^{2}$. Pre-sowing fertilization was used in an amount of $31 \mathrm{~kg} \mathrm{P}$, $66 \mathrm{~kg} \mathrm{~K}$ and $80 \mathrm{~kg} \mathrm{~N} \mathrm{ha}^{-1}$. At the beginning of the stem elongation, the second dose of $\mathrm{N}$ was applied in dose of $30 \mathrm{~kg} \mathrm{~N} \mathrm{ha}^{-1}$. For weed control, Lintur $70 \mathrm{WG}$ in a dose of $150 \mathrm{~g} \mathrm{ha}^{-1}$ (dicamba, $988 \mathrm{~g} \mathrm{ha}^{-1}+$ triasulfuron, $61.5 \mathrm{~g} \mathrm{ha}^{-1}$ ) was used at BBCH $22-24$. To protect the barley against fungal diseases, Capalo $337.5 \mathrm{SE}$ in a dose of $1.5 \mathrm{~L} \mathrm{ha}^{-1}$ (metrafenone, $112.5 \mathrm{~g} \mathrm{ha}^{-1}+$ epoxiconazole, $93.8 \mathrm{~g} \mathrm{ha}^{-1}+$ fenpropimorph, $300 \mathrm{~g} \mathrm{ha}^{-1}$ ) was used at BBCH $34-39$ and Alert 375 $\mathrm{SC}$ in a dose of $1 \mathrm{~L} \mathrm{ha}^{-1}$ (carbendazim, $250 \mathrm{~g} \mathrm{ha}^{-1}+$ flusilazole, $125 \mathrm{~g} \mathrm{ha}^{-1}$ ) at $\mathrm{BBCH} 51-59$. For pest control, Bi58 $400 \mathrm{EC}$ in a dose of $0.5 \mathrm{~L} \mathrm{ha}^{-1}$ (dimethoate, $200 \mathrm{~g} \mathrm{ha}^{-1}$ ) was used at BBCH 59. The harvest of barley grain was performed at the beginning of August.

At flowering stage (BBCH 75), the generative tiller number on the area of $1 \mathrm{~m}^{2}$ and generative tiller length on 30 randomly chosen tillers were determined. At the same time, the dry matter of roots was determined based on 20 successive plants in a row. At the end of ripening (BBCH 89) on 30 randomly selected spikes from each plot the number of grains per spike was determined. The grain yield and moisture were determined directly after harvest. The straw weight was measured $6-8$ days after the grain harvest. One to two months after the grain harvest the 1000 grain weight was also assessed according to the method PN-
68/R-74017. The yield of spring barley grain and straw weight were converted to the determined humidity of $14 \%$. For each plot, the harvest index was calculated (the dry matter of grain yield divided by the sum of the dry matter of grain and straw yields). Mineralization of grain was performed by wet combustion with sulphuric acid and perhydrol (PN-91/R-04014). The content of $\mathrm{P}, \mathrm{N}$ and $\mathrm{K}$ were made using the following methods: PN-ISO 6491, PN-EN ISO 2048, and PNEN ISO 6869, respectively. The uptake of phosphorus, nitrogen, and potassium was calculated for each plot as the product of grain dry matter yield and the microelement content in grain.

The results were analysed using the 'Analysis of variance' statistical program by the UTP University of Science and Technology. The differences between the means were verified with Tukey's test and the significance level $\mathrm{p}=0.05$. Pearson's correlation analyses were carried out using the Statistica for Windows.

\section{Results and Discussion}

Preparations produced from algae may have a favourable effect on barley growth. In the study by Möller \& Smith (1999) it was indicated that priming in seaweed (Ascophyllum nodosum) suspension was beneficial to seed germination. Seaweed (Ecklonia maxima) application at later developmental stages may also be favourable, though there are few studies on this subject (Featonby-Smith \&Van Staden, 1987; Matysiak \& Adamczewski, 2006).

In the current study, the early application of biostimulant at the tillering (BBCH 22), in a dose of $2 \mathrm{~L} \mathrm{ha}^{-1}$, and sequential, in two doses of $1.5 \mathrm{~L} \mathrm{ha}^{-1}$ at the tillering and shooting stages (BBCH 22 and 31), resulted in an increase in the barley root weight in comparison with the control group (Table 1). Barley root growth after the application of extract from algae (Ascophyllum nodosum) has also been reported by other scientists (Steveni, Norrington-Davies, \& Hankins, 1992). Horoszkiewicz-Janka \& Jajor (2006), however, did not observe a difference in the root weight after the use of algae (Ecklonia maxima) biostimulant in comparison with the control group, but in that study, the biopreparation was used for seed dressing. Stimulation of the root system development can be attributed to phytohormones contained in algae, and particularly to auxins (Tarakhovskaya, Maslov, \& Shishova, 2007; Kurepin, Zaman, \& Pharis, 2014). Apart from that, Kelpak also contains other active compounds including cytokinins, polyamines and brassinosteroids (Stirk et al., 2014; Stirk \& Van Staden, 2014).

In the current study no significant effect of the use of biostimulant on density or generative tiller length was observed (Table 1). The straw yield increase, in 
Biometric features and yield of barley depending on biostimulant

Table 1 rate and growth stage during application, means from $2009-2011$

\begin{tabular}{|c|c|c|c|c|}
\hline \multirow[b]{2}{*}{ Characteristics } & \multicolumn{4}{|c|}{ Biostimulant rate and growth stage of barley } \\
\hline & $\begin{array}{c}2 \mathrm{~L} \mathrm{ha}^{-1} \\
\text { BBCH } 22\end{array}$ & $\begin{array}{c}1.5 \mathrm{~L} \mathrm{ha}^{-1} \\
\mathrm{BBCH} 22 \\
1.5 \mathrm{~L} \mathrm{ha}^{-1} \\
\text { BBCH } 31\end{array}$ & $\begin{array}{c}2 \mathrm{~L} \mathrm{ha}^{-1} \\
\text { BBCH } 31\end{array}$ & Control \\
\hline Root weight ${ }^{\dagger}, \mathrm{g}$ & $14.2 \mathrm{a}^{\ddagger}$ & $14.4 \mathrm{a}$ & $12.8 \mathrm{~b}$ & $12.3 \mathrm{~b}$ \\
\hline Generative tiller length, cm & $57.5 \mathrm{a}$ & $56.7 \mathrm{a}$ & $57.4 \mathrm{a}$ & $57.0 \mathrm{a}$ \\
\hline Generative tiller density, no $\mathrm{m}^{-2}$ & $975 \mathrm{a}$ & $980 \mathrm{a}$ & $981 \mathrm{a}$ & $956 a$ \\
\hline Grain number per spike, no & $21.3 \mathrm{a}$ & $21.1 \mathrm{a}$ & $21.1 \mathrm{a}$ & $20.5 b$ \\
\hline Thousand grain weight, $\mathrm{g}$ & $41.3 \mathrm{a}$ & $40.9 \mathrm{a}$ & $40.0 \mathrm{~b}$ & $39.6 b$ \\
\hline Grain yield, $\mathrm{kg} \mathrm{ha}^{-1}$ & $6141 \mathrm{a}$ & $5975 b$ & $5912 b$ & $5909 b$ \\
\hline Straw yield, $\mathrm{kg} \mathrm{ha}^{-1}$ & $5726 \mathrm{~b}$ & $5936 b$ & $6162 \mathrm{a}$ & $5820 \mathrm{~b}$ \\
\hline Harvest index & $0.507 \mathrm{a}$ & $0.489 \mathrm{~b}$ & $0.475 b$ & $0.491 \mathrm{ab}$ \\
\hline
\end{tabular}

†dry root weight from 20 plants; ${ }^{*}$ within a row for each characteristic, values followed by different letters are significantly different according to LSD (0.05).

turn, was recorded for the late application $\left(2 \mathrm{~L} \mathrm{ha}^{-1}\right.$ at $\mathrm{BBCH}$ 31). The early use of the biostimulant resulted in a significant increase in the harvest index in comparison with the late and sequential treatment. The early application of the biostimulant (BBCH 22) in a dose of $2 \mathrm{~L} \mathrm{ha}^{-1}$ resulted in an increase in the grain yield in comparison with the control group. This application method also resulted in an increase in the thousand grain weight. Positive effects of application of the extract from algae were also obtained for the number of grains per spike, for which a positive correlation with grain yield was proved (Table 2). Featonby-Smith \& Van Staden (1987) also have indicated stimulation of traits connected with shaping the barley grain yield as affected by the seaweed concentrate. They showed an increase in grain weight per plant, largely due to a greater number of fertile spikelets per spike. An increase in the spring barley grain yield under the influence of foliar application of the biostimulant from algae was also reported by Matysiak \& Adamczewski (2006).

In our study, the grain yield of spring barley was positively correlated with the root weight, tiller length and their density, and negatively with the thousand grain weight (Table 2). A positive correlation was seen between the number of grains per spike with the root weight, straw yield and generative tiller length, and a negative correlation between the number of grains per spike with the thousand grain weight. The thousand grain weight, in turn, was negatively correlated with the root weight and the tiller length. The correlation between the tiller length and the root weight was also positive. The straw yield was positively correlated with the generative tiller length, root weight and grain yield. There was a negative correlation of the harvest index with the thousand grain weight and positive with

Table 2

Pearson's correlation coefficients for the relation between biometric features and yield of barley

\begin{tabular}{|l|l|l|l|l|l|l|l|}
\hline \multicolumn{1}{|c|}{ Characteristics } & \multicolumn{1}{c|}{1.} & \multicolumn{1}{c|}{2.} & \multicolumn{1}{c|}{3.} & \multicolumn{1}{c|}{4.} & 5. & 6. & 7. \\
\hline 1. $\quad$ Root weight, g & & & & & & & \\
\hline 2. Generative tiller length, cm & $0.64^{*}$ & & & & & & \\
\hline 3. Generative tiller density, no m ${ }^{-2}$ & $-0.09 \mathrm{~ns}$ & $0.08 \mathrm{~ns}$ & & & & & \\
\hline 4. Grain number per spike, no & $0.69^{*}$ & $0.95^{*}$ & $0.19 \mathrm{~ns}$ & & & & \\
\hline 5. Thousand grain weight, $\mathrm{tha}^{-1}$ & $-0.47^{*}$ & $-0.83^{*}$ & $0.20 \mathrm{~ns}$ & $-0.74^{*}$ & & & \\
\hline 6. Grain yield, $\mathrm{kg} \mathrm{ha}^{-1}$ & $0.57^{*}$ & $0.82^{*}$ & $0.40^{*}$ & $0.88^{*}$ & $-0.47^{*}$ & & \\
\hline 7. Straw yield, $\mathrm{kg} \mathrm{ha}^{-1}$ & $0.54^{*}$ & $0.82^{*}$ & $0.20 \mathrm{~ns}$ & $0.79^{*}$ & $-0.64^{*}$ & $0.73^{*}$ & \\
\hline 8. Harvest index & $0.50^{*}$ & $0.71^{*}$ & $0.38^{*}$ & $0.80^{*}$ & $-0.38^{*}$ & $0.94^{*}$ & $0.47^{*}$ \\
\hline
\end{tabular}

* significant at $\mathrm{p}<0.05 ; \mathrm{ns}-$ non significant 


\section{Content and uptake of $\mathrm{N}, \mathrm{P}, \mathrm{K}$ in barley grain depending on biostimulant rate and growth stage during application, means from 2009- 2011}

\begin{tabular}{|c|c|c|c|c|}
\hline \multirow[b]{2}{*}{ Macroelement } & \multicolumn{4}{|c|}{ Biostimulant rate and growth stage of barley } \\
\hline & $\begin{array}{c}2 \mathrm{~L} \mathrm{ha}^{-1} \\
\text { BBCH } 22\end{array}$ & $\begin{array}{l}1.5 \mathrm{~L} \mathrm{ha}^{-1} \\
\mathrm{BBCH} 22 \\
1.5 \mathrm{~L} \mathrm{ha}^{-1} \\
\mathrm{BBCH} 31\end{array}$ & $\begin{array}{c}2 \mathrm{~L} \mathrm{ha}^{-1} \\
\text { BBCH } 31\end{array}$ & Control \\
\hline \multicolumn{5}{|l|}{ Content, $\mathrm{g} \mathrm{kg}^{-1}$} \\
\hline $\mathrm{N}$ & $16.3 \mathrm{a}^{\ddagger}$ & $16.3 \mathrm{a}$ & $16.6 \mathrm{a}$ & $16.4 \mathrm{a}$ \\
\hline $\mathrm{P}$ & $3.57 \mathrm{~b}$ & $3.60 \mathrm{a}$ & $3.56 b$ & $3.57 \mathrm{~b}$ \\
\hline K & $3.65 \mathrm{c}$ & $3.68 \mathrm{~b}$ & $3.71 \mathrm{a}$ & $3.70 \mathrm{a}$ \\
\hline \multicolumn{5}{|l|}{ Uptake, $\mathrm{kg} \mathrm{ha}^{-1}$} \\
\hline $\mathrm{N}$ & $84.4 \mathrm{a}$ & $81.9 \mathrm{~b}$ & $81.8 \mathrm{~b}$ & $81.5 \mathrm{~b}$ \\
\hline $\mathrm{P}$ & $19.1 \mathrm{a}$ & $18.6 \mathrm{~b}$ & $18.2 b$ & $18.4 \mathrm{~b}$ \\
\hline K & $18.5 \mathrm{a}$ & $18.1 \mathrm{a}$ & $17.8 \mathrm{a}$ & $18.0 \mathrm{a}$ \\
\hline
\end{tabular}

${ }^{\ddagger}$ within a row for each macroelement, values followed by different letters are significantly different according to LSD (0.05).

the root weight, generative tiller length and density, as well as with the number of grains per spike and with the grain and straw yield.

No significant effect of the seaweed biostimulant on $\mathrm{N}$ content in the spring barley grain was indicated (Table 3). Sequential use of the preparation resulted in an increase in P content in the grain, as compared with the control group and the other application variants. The early and sequential applications of the biostimulant resulted in a decrease in $\mathrm{K}$ content in the spring barley grain, as compared with the control group and late treatment. The uptake of $\mathrm{N}$ and $\mathrm{P}$ in grain was the highest after a single application of the preparation at the tillering stage (early treatment). No significant effect of the biostimulant application on $\mathrm{K}$ uptake was indicated.

In the current study, $\mathrm{N}$ and $\mathrm{P}$ uptake in barley grain was determined mainly with the grain yield quantity. Due to the lack of influence of the preparation on $\mathrm{N}$ content or a small effect on $\mathrm{P}$ concentration, the uptake of those elements in the grain was the highest after the application, resulting in the growth of yield (single early treatment). Potassium uptake, in spite of smaller concentration in grain in early and sequential treatments, was similar to the application of biostimulant and in the control group. The lack and even a negative response of the macroelement $\mathrm{N}, \mathrm{P}$ and $\mathrm{K}$ content in the barley grain to the biostimulant application may result from genetic traits of the studied barley cultivar. According to Carvalho et al. (2014), the effect of the use of extracts from algae depends not only on the dose, method, and time of application, but also on the cultivar sensitivity. The integration of cultivation methods and improvement of varietal traits may bring about a significant increase in the effectiveness of nutrient utilization,affecting barley grain yield quantity and quality (Anabessa \& Juskiw, 2012).

\section{Conclusions}

1. The response of spring barley to the foliar application of seaweed (Ecklonia maxima Osbeck) biostimulant Kelpak depended on the dose and developmental stage of plants during the application.

2. Early application of biostimulant (in a dose of 2 $\mathrm{L} \mathrm{ha}^{-1}$ at $\mathrm{BBCH} 22$ ) had a favourable effect on the number of grains per spike, thousand grain weight, and grain yield of spring barley. This application method stimulated the growth of root weight and resulted in an increase in $\mathrm{N}$ and $\mathrm{P}$ uptake in grain.

3. Favourable response of the grain yield and nutrient uptake gives grounds for recommendations of the foliar application of seaweed biostimulant Kelpak in early treatment for spring barley. There is a need for further field studies on the effect of the preparation application in conditions of growing biotic and abiotic stress.

\section{Acknowledgements}

The authors would like to acknowledge Elżbieta Skotnicka for her assistance in the field experiments.

\section{References}

1. Anabessa, Y., \& Juskiw, P. (2012). Strategies to increase nitrogen use efficiency of spring barley. Canadian Journal of Plant Science, 92, 617-625. 
2. Carvalho, M.E., Castro, P.R., Gallo, L.A., \& Ferraz, M.V. (2014). Seaweed extract provides development and production of wheat. Revista Agrarian, 7(23), 166-170.

3. Craigie, J. (2011). Seaweed extract stimuli in plant science and agriculture. Journal of Applied Phycology, 23, 371-393. DOI: 10.1007/s10811-010-9560-4.

4. EBIC. European Biostimulant Industry Council (2014). EBIC and biostimulants in brief. Retrieved February 12, 2018, from: http://www.biostimulants.eu.

5. FAOSTAT. (2016). FAO Statistics Division. Retrieved February 20, 2018, from: http://faostat3.fao.org.

6. Featonby-Smith, B.C., \& Van Staden, J. (1987). Effects of seaweed concentrate on grain yield in barley. South African Journal of Botany, 52, 125-128.

7. Horoszkiewicz-Janka, J., \& Jajor, E. (2006). Wpływ zaprawiania nasion na zdrowotność roślin jęczmienia, pszenicy i rzepaku w początkowych fazach rozwoju (The effect of seed dressing on healthiness of barley, wheat and rape in early development stages). Journal of Research and Applications in Agricultural Engineering, 51(2), 47-53. (in Polish).

8. IUSS Working Group WRB (2014). World Reference Base for Soil Resources 2014. International soil classification system for naming soils and creating legends for soil maps. World Soil Resources Reports 106, FAO, Rome: 181 pp.

9. Khan, W., Rayireth, U., Subramanian, S., Jithesh, M., Rayoreth, P., Hodges, M., ... Prithiviraj, B. (2009). Seaweed extracts as biostimulants of plant growth and development. Journal of Plant Growth Regulation, 28, 386-399. DOI: 10.1007/s00344-009-9103-x.

10. Kocira, S., Kocira, A., Kornas, R., Koszel, M., Szmigielski, M., Krajewska, M., ... Krzysiak, Z. (2017). Effects of seaweed extract on yield and protein content of two common bean (Phaseolus vulgaris L.) cultivars. Legume Research, 383, 1-5. DOI: 10.18805/LR-383.

11. Kotwica, K., Jaskulska, I., Gałęzewski, L., Jaskulski, D., \& Lamparski, R. (2014). Spring wheat yield in short-term monoculture depending on the tillage method, use of organic matter and a biostimulant. Acta Scientiarum Polonorum, Agricultura, 13(2), 19-28.

12. Kurepin, L., Zaman, M., \& Pharis, R.P. (2014). Phytohormonal basis for the plant growth promoting action of naturally occurring biostimulators Journal of the Science of Food and Agriculture, 94, 1715-1722. DOI: $10.1002 /$ jsfa.6545.

13. Matysiak, K., \& Adamczewski, K. (2006). Wpływ bioregulatora Kelpak na plonowanie roślin uprawnych. (Influence of bioregulator Kelpak on yield of cereals and other crops) Progress in Plant Protection, 46, 2 , 102-108. (in Polish).

14. Möller, M., \& Smith, M.L. (1999). The effects of priming treatments using seaweed suspensions on the water sensitivity of barley (Hordeum vulgare L.) caryopses. Annals of Applied Biology, 135, 2, 515-521. DOI: $10.1111 / \mathrm{j} .1744-7348.1999 . t b 00882 . x$.

15. PN-68/R-74017 (1968). Ziarno zbóż i nasiona strączkowe jadalne - oznaczanie masy 1000 ziaren (Cereal grains and edible leguminous seeds - 1000 grain weight determination). (in Polish).

16. PN-91/R-04014 (1991). Analiza chemiczno-rolnicza roślin - metody mineralizacji materiału roślinnego do oznaczania makro - i mikroelementów (Chemical and agricultural analysis of plants - methods of mineralization of plant material for the determination of macro- and microelements). (in Polish).

17. PN-EN ISO 20483 (2007). Ziarno zbóż i nasiona roślin strączkowych - oznaczanie zawartości azotu i przeliczanie na zawartość białka (Cereal grains and leguminous seeds - determination of nitrogen and conversion into protein). (in Polish)

18. PN-EN ISO 6869 (2002). Pasze - oznaczanie zawartości wapnia, miedzi, żelaza, magnezu, manganu, potasu, sodu i cynku (Feed - determination of calcium, copper, iron, magnesium, manganese, potassium, sodium and zinc). (in Polish).

19. PN-ISO 10390. (1997). Jakość gleby - oznaczanie pH (Soil quality - determination of pH). (in Polish).

20. PN-ISO 10694 (2002). Jakość gleby - oznaczanie zawartości węgla organicznego i całkowitej zawartości węgla po suchym spalaniu (Soil quality - determination of organic carbon and total carbon after dry combustion). (in Polish).

21. PN-ISO 6491 (2000). Pasze - oznaczanie zawartości fosforu (Feed - determination of phosphorus). (in Polish).

22. PN-R-04022 (1996). Analiza chemiczno-rolnicza gleb - oznaczanie zawartości przyswajalnego potasu w glebach mineralnych (Chemical and agricultural analysis of soil - determination of available potassium in mineral soils). (in Polish).

23. PN-R-04023 (1994). Analiza chemiczno-rolnicza gleby - oznaczanie zawartości przyswajalnego magnezu (Chemical and agricultural analysis of soil - determination of available magnesium). (in Polish). 
24. PN-R-04023 (1996). Analiza chemiczno-rolnicza gleby - oznaczanie zawartości przyswajalnego fosforu w glebach mineralnych (Chemical and agricultural analysis of soil - determination of available phosphorus in mineral soils). (in Polish).

25. PN-R-04028 (1997). Analiza chemiczno-rolnicza gleby - metoda pobierania próbek i oznaczanie zawartości jonów azotanowych i amonowych w glebach mineralnych (Chemical and agricultural analysis of soil - the method of sampling and determination of ammonium and nitrate ions in mineral soils). (in Polish).

26. Sangha, J.S., Kelloway, S., Critchley, A.T., \& Prithiviraj, B. (2014). Seaweeds (Macroalgae) and their extracts as contributors of plant productivity and quality. The current status of our understanding. Advances in Botanical Research, 71, 189-219. DOI: 10.1016/B978-0-12-408062-1.00007-X.

27. Sharma, S.H.S., Fleming, C., Selby, Ch., Rao, J.R., \& Trevor, M. (2014). Plant biostimulants: a review on the processing of macroalgae and use of extracts for crop management to reduce abiotic and biotic stresses. Journal of Applied Phycology, 26, 465-490. DOI: 10.1007/s10811-013-0101-9.

28. Steveni, C.M., Norrington-Davies, J., \& Hankins, S.D. (1992). Effect of seaweed concentrate on hydroponically grown spring barley. Journal of Applied Phycology, 4, 173-180. DOI: 10.1007/BF02442466.

29. Stirk, W., Tarkowska D., Turecova, V., Strand M., \& Van Staden, J. (2014). Abscisic acid, gibberellins and brassinosteroids in Kelpak and commercial seaweed extract made from Ecklonia maxima. Journal of Applied Phycology, 26, 2, 561-567. DOI: 10.1007/s10811-013-0062-z.

30. Stirk, W.A., \& Van Staden, J. (2014). Plant growth regulators in seaweeds: Occurrence, regulation and functions. Advances in Botanical Research, 71, 125-159. DOI: 10.1016/B978-0-12-408062-1.00005-6.

31. Szczepanek, M., Wszelaczyńska, E., \& Pobereżny, J. (2018). Effect of the seaweed biostimulant application in spring wheat. AgroLife Scientific Journal 7, 1, 131-136.

32. Tarakhovskaya, E.R, Maslov, Y.I., \& Shishova, M.F. (2007). Phytohormones in algae. Russian Journal of Plant Physiology, 54(2), 163-170. DOI: 10.1134/S1021443707020021. 